\title{
Simulation of Total Dry Matter Production of (Glycine Max L. Merrill) Under Weed Management Practices
}

\author{
Hossein Mohammadi, Hassan Rahnaward Ghulami, Abdul Qayom Rezaei
}

\begin{abstract}
An investigation on "Weed Management and Crop Growth Modeling in Soybean" was carry out on red sandy loam soil at UAS, Main Research Station, Hebbal, Bangalore during Rabi 2010 (September to December). The weed control practices included in the study were i) Pendimethalin 30 EC $1.0 \mathrm{~kg} \mathrm{a.i./ha-}$ 3 days after sowing, ii) Imazethapyr 10 SL $100 \mathrm{~g}$ a.i./ha - 20 days after sowing, iii) Quizalofop-p-ethyl 5 EC $50 \mathrm{~g}$ a.i./ha - 20 days after sowing, iv) Chlorimuron ethyl 25 WP $6 \mathrm{~g}$ a.i./ha - 20 days after sowing, v) Hand weeding (20 \& 40 DAS) and vi) un-weeded control. The experiment was designed as RCBD with four replications. Growth models - Richards, Logistic, Cubic polynomial and Quadratic polynomial simulated the course of dry matter production/plant by $>97$ per cent under all weed management practices, indicating that weed competition did not alter the pattern of crop growth, but affected the total production substantially.
\end{abstract}

Keywords: Soybean, Simulation of total dry matter production, Weed management practices

\section{INTRODUCTION}

$\mathrm{S}_{\text {hift in weed flora is resulted from selection pressures }}$ imposed by modifications in the agricultural practices which alter their habitat directly or indirectly. This selection pressure has brought in many new problems like susceptible weeds becoming resistant owing to continuous use of herbicides having similar mode of action, recent trends of using very low doses of highly potent herbicides, reduced tillage and less turnaround time under highly intensive farming system. Thus suitable choice of weed management practice is needed for crops, to sustain high productivity at a reasonable cost. The traditional methods of weed control by hand weeding or mechanical means are now becoming costly, tedious, labour intensive and time consuming, and at times not able to be adopted in view of non-availability of laborers.With the availability of computers for analysis, mathematical models are being developed to quantify yield losses due to weed competition and to study the differential responses of weeds to herbicides [1].

Manuscript received on 28 August 2021 | Revised Manuscript received on 13 September 2021 | Manuscript Accepted on 15 October 2021 | Manuscript published on 30 October 2021.

* Correspondence Author

Dr. Hossein Mohammadi, Assistant Professor and Deputy of the Agriculture Faculty, Bamyan University, Bamyan, Afghanistan.

Hassan Rahnaward Ghulami*, Assistant Professor in the Natural Science Faculty, Bamyan University, Bamyan, Afghanistan.

Dr. Abdul Qayom Rezaei, Assistant Professor and Dean of Agriculture Faculty, Bamyan University, Bamyan, Afghanistan.

(C) The Authors. Published by Lattice Science Publication (LSP). This is an open access article under the CC-BY-NC-ND license (http://creativecommons.org/licenses/by-nc-nd/4.0/)
From these, functional models were worked out under different weed management practices and the quantum of yield loss occurring in the field due to weeds was also worked out. In the eighth and the ninth five year plans, greater emphasis has been laid on increasing the production of oilseed crops to reduce the import of edible oils. Of the oilseeds, leguminous oilseed like soybean is also one needing greater attention. Cost effective weed management technique is an important requirement for increased production. Non-availability of labour at the required time coupled with higher wages and introduction of newer herbicides with greater weed control efficiency have made the task of weed management more challenging. Development of herbicide technology for commercially viable crops will have greater scope viz., increased adoption by the farmers.

\section{MATERIAL AND METHODS}

An investigation on "Weed Management and Crop Growth Modeling in Soybean" was carry out on red sandy loam soil at UAS, Main Research Station, Hebbal, Bangalore during Rabi 2010 (September to December). The weed management practices included in the study were i) Pendimethalin 30 EC $1.0 \mathrm{~kg}$ a.i. /ha -3 days after sowing, ii) Imazethapyr $10 \mathrm{SL}$ $100 \mathrm{~g}$ a.i. /ha -20 days after sowing, iii) Quizalofop-p-ethyl 5 EC $50 \mathrm{~g}$ a.i. /ha -20 days after sowing, iv) Chlorimuron ethyl 25 WP 6 g a.i. /ha -20 days after sowing, v) Hand weeding (20 \& 40 days after sowing) and vi) un-weeded control. The experiment was laid out as randomized complete block design with four replications. The soybean variety used was JS- 335 (Jawahar soybean 335). The parentage is JS 78-77 (Kohar $x$ P.S 73-22) x 71-05. The variety is of early maturity (100 days duration) with resistance to major diseases and pests. The recommended dose of FYM $6.25 \mathrm{t} / \mathrm{ha}$ was applied at the time of sowing of crop. The seed of soybean was treated with PSB $500 \mathrm{~g} / \mathrm{ha}$ and Rhizobium $500 \mathrm{~g} / \mathrm{ha}$ before sowing. The entire quantity of recommended fertilizer dose of $30 \mathrm{~kg} \mathrm{~N}, 80 \mathrm{~kg}$ P2O5, $38 \mathrm{~kg} \mathrm{K2O} \mathrm{and} \mathrm{Zn} 20 \mathrm{~kg} / \mathrm{ha}$ was applied at the time of sowing. Furrows were opened at $30 \mathrm{~cm}$ row spacing and in these furrows fertilizers were placed and mixed thoroughly into the soil. The crop was harvested on 21st December 2010. Five tagged plants were randomly selected in each net plot area for making periodical observations on yield attributing parameters. The crop in the net plot was harvested and threshed separately. The pods and haulm portion were sundried for a week and dry weight was recorded as per treatment and converted to hectare.

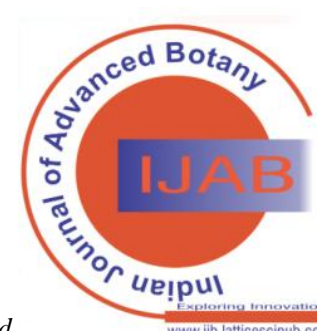




\section{Simulation of Total Dry Matter Production of (Glycine Max L. Merrill) Under Weed Management Practices}

The data on course of total dry matter production (g/plant) of soybean at harvest under six weed management practices were fitted to the following functional models to understand the growth differences due to weed competition.

Following five models were fitted to the data:

1) Polynomial - Linear $Y=a+b X+e$.

2) Polynomial - Quadratic $Y=a+b X+c X^{2}+e$.

3) Cubic polynomial $Y=a+b X+c X^{2}+d X^{3}+e$.

4) Logistic function $Y=y_{\max }[1+\exp (\beta-k x)]^{-1}$.

5) Richards function $Y=y_{\max }[1+\exp (\beta-k x)]^{-y n}$.

Where, $Y=$ Total dry matter production, g/plant;

$y_{\max }=$ Maximum Yield assumed to be attainable in the field

$X=$ Stages of crop growth in days.

$e=$ Error component.

$a, b, c, d, \beta, k$ and $n$ are constants to be worked out in the functional models.

\section{RESULTS AND DISCUSSIONS}

Total dry matter production was regressed for various stages in days by using linear, quadratic, cubic, Logistic and Richards function under various weed management practices and provided in Table 1 Under all weed management practices, growth models namely Logistic, Richards and cubic polynomial models simulated total dry matter production per plant at various growth stages by more than 98 to $99 \%$, indicating similarity in crop growth. The next best model was quadratic (2nd order polynomial) which simulated 97.2 to 98.9 per cent total plant dry matter production nearer to the actual data. Whereas, linear model simulated total dry matter production of soybean by 94.4 to 95.3 per cent under various weed management practices. However, the differences in R2 between polynomial 2nd degree and 3rd degree, Logistic and Richards functions were not much. This suggested that crop growth of soybean was unaltered by weed competition as explained by similar coefficient of prediction obtained under all weed management practices including un-weeded control (with all weed types' competition) and chlorimuron ethyl (with grassy weeds' competition). As observed in the present study, Ramachandra Prasad [2] in sunflower, Jayarama [3] in groundnut, Shobha [4] in soybean, and Qasem [5] in maize observed no change in the course of crop growth pattern due to weed competition, but affected the quantum of total dry matter production/plant

Linear function was differentiated to get the daily rate of dry matter production per plant (g/plant/day) i.e. regression coefficient. This is also called as Absolute Growth rate (AGR) (Table 2). Treatments receiving pendimethalin, hand weeding, quizalofop-p-ethyl and imazethapyr resulted AGR of 0.224 to $0.252 \mathrm{~g} / \mathrm{plant} /$ day as against $0.161 \mathrm{~g} / \mathrm{plant} /$ day in un-weeded control soybean with competition of all weed types and $0.219 \mathrm{~g} /$ plant/day in chlorimuron ethyl treated soybean with competition from grasses (Table 2). Thus, all weed types' competition from the critical stage as noticed in un-weeded control caused $36 \%$ reduction in daily rate of dry matter production in soybean, followed by competition from grasses, as in chlorimuron ethyl treatment, which gave $13 \%$ reduction in Absolute Growth Rate. The relative growth of dry matter production termed as absolute growth rate (AGR) was worked out to quantify the ill effect of weed competition. Competition from all weed types - grasses, sedge and broad leaf weeds observed in un-weeded control lowered the AGR by 36 per cent as compared to the treatment receiving imazethapyr with less weeds' competition, while the grassy weeds' competition observed in chlorimuron ethyl treatment lowered AGR by 13 per cent and broad leaf weeds' competition observed in quizalofop-p-ethyl treatment lowered AGR by 4 per cent. Thus, grasses by virtue of higher competitive ability lowered the total dry matter production in soybean, by lowering the growth rate, as also stated by [4] in soybean and [3] in groundnut. As observed in the present study with better simulation of dry matter of soybean by using Logistic and Richards growth functions, [6] in sesame, [7] in winged bean, [8], [9] in maize, [8] in sunflower, have also obtained better prediction of dry matter with Logistic, Gompertz and Richards functions under various agronomic manipulations.

\section{CONCLUSION}

Under all weed management practices, growth models namely Logistic, Richards and cubic polynomial models simulated total dry matter production per plant at various growth stages by more than 98 to $99 \%$, indicating similarity in crop growth. The next best model was quadratic (2nd order polynomial) which simulated 97.2 to 98.9 per cent total plant dry matter production nearer to the actual data. Whereas, linear model simulated total dry matter production of soybean by 94.4 to 95.3 per cent under various weed management practices. However, the differences in R2 between polynomial 2nd degree and 3rd degree, Logistic and Richards functions were not much. Linear function was differentiated to get the daily rate of dry matter production per plant (g/plant/day) i.e. regression coefficient. This is also called as Absolute Growth rate (AGR). Treatments receiving pendimethalin, hand weeding, quizalofop-p-ethyl and imazethapyr resulted AGR of 0.224 to $0.252 \mathrm{~g} /$ plant/day as against $0.161 \mathrm{~g} / \mathrm{plant} /$ day in un-weeded control soybean with competition of all weed types and $0.219 \mathrm{~g} /$ plant/day in chlorimuron ethyl treated soybean with competition from grasses.

\section{REFERENCES}

1. R. Cousens, "Aspects of the design and interpretation of competition (interference) experiments," Weed Technol., vol. 5, no. 3, pp. 664-673, 1991. [CrossRef]

2. T. R. Prasad, "Weed Management and Crop Growth Modeling in Sunflower-and Groundnut Based Cropping Systems," PhD Thesis, Tamil Nadu Agricultural University, Coimbatore, 1993.

3. K. A. Jayarama, "FUNCTIONAL GROWTH MODEL IN RELATIONTO WEED MANAGEMENT IN GROUNDNUT (Arachis hypogaea L.)," $\mathrm{PhD}$ Thesis, University of Agricultural Sciences GKVK, Bangalore, 2000.

4. R. Shobha, "Weed Management and Weed Threshold Models in Soybean (Glycine Max L. Merrill)," PhD Thesis, University of Agricultural Science, Dharwad, 2001.

5. J. R. Qasem, "Applied allelopathy in weed management: an update," in Allelopathy, Springer, 2013, pp. 251-297. [CrossRef] 
6. V. P. Rao, "Application of logistic model for predicting sesame dry matter.," J. Res. APAU, vol. 18, no. 2, pp. 172-174, 1990.

7. R. R. Weil and G. S. Belmont, "Dry matter and nitrogen accumulation and partitioning in field grown winged bean," Exp. Agric., vol. 27, no. 3, pp. 323-328, 1991. [CrossRef]

8. T. V. Ramachandra Prasad, S. P. Palaniappan, C. Suyambulingom, and A. Rajagopal, "Comparison of Empirical Models to Simulate Crop Growth and Relative Growth Rate in Sunflower (Helianthus annus L.)
Cultivars," Proc.-INDIAN Natl. Sci. Acad. PART B, vol. 62, pp. 159-168, 1996.

9. T. V. Ramachandra Prasad and K. Shiva Shankar, "Mathematica models to describe dry matter and cob growth in maize (Zea mays L.) cultivars [in India]," Maydica Italy, 1992. [CrossRef]

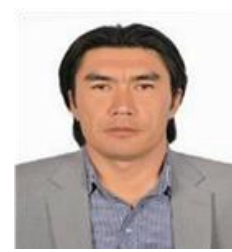

\section{AUTHORS PROFILE}

Dr. Hossein Mohammadi, UKM, Faculty of Science and Technology, Kuala Lumpur, Malaysia, Ph.D in Agriculture; UAS, GKVK, Agronomy Department, Bangalore, India. (Master's Degree in Agriculture), Kabul University, Agricultural faculty, Agronomy Department, Kabul, Afghanistan, Bachelor's Degree in Agronomy. Published four journal paper internationally and three paper have published in the journal of Bamyan university. Achievement: awarded Bachelor Certificate, Master Certificate and PhD Certificate.

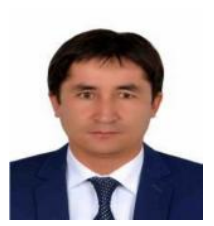

Hassan Rahnaward Ghulami, graduated as Master of Science (Statistics) from University Malaysia Pahang (UMP), and got bachelor degree in pure Mathematics from Kabul University. Published three journal papers which are indexed Scopus, and participated in three conference proceeding. My poster presentation entitled "Students Attitudes towards learning of statistics: A case study in UMP" in Creation, Innovation, Technology \& Research Exposition (CITREX)" received bronze medal and although my paper entitled "Relationship between Internet addictions and academic performance among Afghan universities students" awarded the best paper. Since 2005, appointed as senior lecturer, dean of research committee in the faculty of natural science, editor in Chief: Scientific- Research journal of Bamyan University.

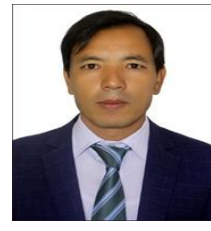

Dr. Abdul Qayom Rezaei was born in the year 1984 in Bamyan province, Afghanistan. He has been graduated from Sachak high school (Bamyan) in 2002 and enrolled as a bachelor student (B.Sc.) in the Horticulture Department of Agriculture Faculty of Kabul University in 2003 and has been graduated in 2006. He completed his master degree in fruit science at University of Agricultural Sciences, Bangalore, India in the year 2011. Rezaei enrolled for PhD in the year 2014 and completed his PhD in International Agricultural Development, Tokyo University of Agriculture, Japan. He is working as a lecturer in Agriculture faculty of Bamyan University since 2007. Rezaei currently working as dean of Agriculture Faculty of Bamyan University and also worked as head of Horticulture Department and dean of Geoscience Faculty as well. He participated in Afghanistan Agricultural Water Conservancy training program at Shihezi University, China from May 30, 2019 to June 18, 2019 and attended on different workshops and short term studies program inside and outside of the country.

\section{APPENDIX}

Table 1: Course of total dry matter production (g/plant) in soybean at different stages under various weed management practices as explained by growth models.

a) Pendimethalin $1.0 \mathrm{~kg}$ a.i./ha as pre-em.

\begin{tabular}{|c|c|c|c|}
\hline Sl. No & Models & Equation & $\boldsymbol{R}^{2}$ \\
\hline 1 & Linear & $Y=-3.502+0.22 X$ & $0.947 * *$ \\
\hline 2 & Quadratic & $Y=-0.601+0.040 X+0.001 X^{2}$ & $0.978 * *$ \\
\hline 3 & Cubic & $Y=0.337-0.169 X+0.007 X^{2}-3.862 X^{3}$ & $0.987 * *$ \\
\hline 4 & Logistic & $Y=\frac{21.07}{\{1+215.962 * \exp (-0.0827 X)\}}$ & $0.994 * *$ \\
\hline 5 & Richards & $Y=\frac{1.90}{\{1+\exp (15.891-0.208 X)\}^{1 / 3.888}}$ & $0.997 * *$ \\
\end{tabular}

b) Imazethapyr $100 \mathrm{~g}$ a.i./ha as post-em.

\begin{tabular}{|c|c|c|c|}
\hline Sl. No. & Models & Equation & $\boldsymbol{R}^{2}$ \\
\hline 1 & Linear & $Y=-4.2498+0.252 X$ & $0.95 * *$ \\
\hline 2 & Quadratic & $Y=-0.695-0.435 X+0.002 X^{2}$ & 2.91 \\
\hline 3 & Cubic & $Y=0.324-0.183 X+0.008 X^{2}-4.198 X^{3}$ & $0.98 * *$ \\
\hline 4 & Logistic & $Y=\frac{23.299}{\{1+210.200 * \exp (-0.0827 X)\}}$ & $0.99 * *$ \\
\hline 5 & Richards & $Y=\frac{21.734}{\{1+\exp (10.651-0.144 X)\}^{1 / 2.434}}$ & 1.74 \\
\hline
\end{tabular}

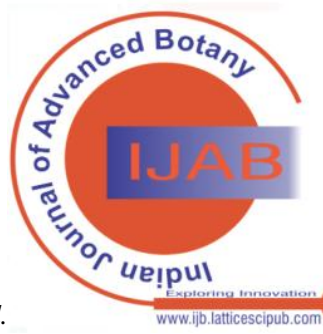


Simulation of Total Dry Matter Production of (Glycine Max L. Merrill) Under Weed Management Practices

c) Quizal.0 kg a.i./ha as ofop-p-ethyl $50 \mathrm{~g}$ a.i./ha as post-em.

\begin{tabular}{|c|c|c|c|c|}
\hline Sl. No & Models & Equation & $R^{2}$ & $S E$ \\
\hline 1 & Linear & $Y=-4.016+0.243 X$ & $0.947 * *$ & 2.65 \\
\hline 2 & Quadratic & $Y=-0.272+0.005 X+0.002 X^{2}$ & $0.978 * *$ & 1.90 \\
\hline 3 & Cubic & $Y=0.281-0.117 X+0.005 X^{2}-2.275 X^{3}$ & $0.987 * *$ & 1.64 \\
\hline 4 & Logistic & $Y=\frac{25.095}{\{1+134.483 * \exp (-0.070 X)\}}$ & $0.994 * *$ & 1.02 \\
\hline 5 & Richards & $Y=\frac{23.818}{\{1+\exp (6.775-0.090 X)\}^{1 / 1.520}}$ & $0.997 * *$ & 0.75 \\
\hline
\end{tabular}

d) Pendimethalin 1 pre-em.

\begin{tabular}{|c|c|c|c|c|}
\hline Sl. No & Models & Equation & $\boldsymbol{R}^{2}$ & SE \\
\hline 1 & Linear & $\mathrm{Y}=-3.341+0.219 \mathrm{X}$ & $0.947^{* *}$ & 2.59 \\
\hline 2 & Quadratic & $\mathrm{Y}=-0.824+0.060 \mathrm{X}+0.001 \mathrm{X}^{2}$ & $0.971^{* *}$ & 2.12 \\
\hline 3 & Cubic & $Y=0.374-0.206 \mathrm{X}+0.008 \mathrm{X}^{2}-4.930 \mathrm{X}^{3}$ & $0.987^{* *}$ & 1.62 \\
\hline 4 & Logistic & $Y=\frac{21.822}{\{1+227.655 \exp (-0.083)\}}$ & $0.995^{* *}$ & 0.90 \\
\hline 5 & Richards & $Y=\frac{18.322}{\{1+\exp (17.5900 .239 \mathrm{X})\}^{1 / .096}}$ & $0.998^{* *}$ & 0.62 \\
\hline
\end{tabular}

e) Imazethapyr $100 \mathrm{~g}$ a.i./ha as post-em.

\begin{tabular}{|c|c|c|c|c|}
\hline SI. No. & Models & Equation & $R^{2}$ & $S E$ \\
\hline 1 & Linear & $Y=-3.560+0.231 X$ & $0.944 * *$ & 2.84 \\
\hline 2 & Quadratic & $Y=-0.636+0.046 \mathrm{X}+0.001 \mathrm{X}^{2}$ & $0.972 * *$ & 2.19 \\
\hline 3 & Cubic & $Y=0.391-0.182 \mathrm{X}+0.008 \mathrm{X}^{2} \pm 4.225 \mathrm{X}^{3}$ & $0.983^{* *}$ & 1.95 \\
\hline 4 & Logistic & $Y=\frac{23.299}{\{1+210.200 * \exp (-0.0827 X)\}}$ & $0.990 * *$ & 1.33 \\
\hline 5 & Richards & $Y=\frac{21.734}{\{1+\exp (10.651-0.144 X)\}^{1 / 2.434}}$ & $0.998 * *$ & 0.71 \\
\hline
\end{tabular}

f) Quizalofop-p-ethyl 50 g a.i./ha as post-em.

\begin{tabular}{|c|c|c|c|c|}
\hline Sl. No & Models & Equation & $R^{2}$ & $S E$ \\
\hline 1 & Linear & $Y=-2.332+0.161 X$ & $0.953^{* *}$ & 1.80 \\
\hline 2 & Quadratic & $Y=-0.460+0.042 \mathrm{X}+0.001 \mathrm{X}^{2}$ & $0.977 * *$ & 1.37 \\
\hline 3 & Cubic & $Y=0.249-0.114 \mathrm{X}+0.005 \mathrm{X}^{2}-2.917 \mathrm{X}^{3}$ & $0.988^{* *}$ & 1.14 \\
\hline 4 & Logistic & $Y=\frac{15.177}{\{1+159.756 \exp (-0.07 X)\}}$ & $0.994 * *$ & 0.73 \\
\hline 5 & Richards & $Y=\frac{13.886}{\{1+\exp (14.6350 .194 \mathrm{x})\}^{1 / 3.744}}$ & $0.997 * *$ & 0.57 \\
\hline
\end{tabular}

Table 2: Impact of weed management practices on rate of dry matter production (AGR) in soybean by differentiating the linear function.

\begin{tabular}{|l|c|c|}
\hline \multicolumn{1}{|c|}{ Weed management practices } & $\begin{array}{c}\text { Absolute Growth Rate } \\
\text { (Regression coefficient, b) } \\
\text { (g/plant/day) }\end{array}$ & $\begin{array}{c}\text { \% Reduction in AGR over } \\
\text { imazethapyr }\end{array}$ \\
\hline $\mathrm{T}_{1}$ - Pendimethalin 30 EC 1.0 kg a.i./ha (Pre-em.)- 3 DAS & 0.224 & 11.1 \\
\hline $\mathrm{T}_{2}$ - Imazethapyr 10 EC 100 g a.i./ha (Post-em.)- 20 DAS & 0.252 & - \\
\hline $\mathrm{T}_{3}$ - Quizalofop-p-ethyl 5 EC 50 g a.i./ha (Post-em.)- 20 DAS & 0.243 & 3.6 \\
\hline $\mathrm{T}_{4}$ - Chlorimuron ethyl 20 WP 6 g a.i./ha (Post-em.)- 20 DAS & 0.219 & 13.1 \\
\hline $\mathrm{T}_{5}$ - Hand Weeding (20 \& 40 DAS) & 0.231 & 8.3 \\
\hline $\mathrm{T}_{6}$ - Unweeded control & 0.161 & 36.1 \\
\hline
\end{tabular}

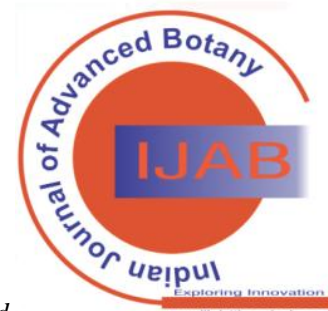

